\title{
Pengaruh Lingkungan dalam Pembelajaran Bahasa Indonesia
}

\section{Dina Hutri Tubagus/19016014}

\section{dinahutritubagus@gmail.com}

Lingkungan hidup yang baik akan mengakibatkan hal-hal yang baik juga, menjaga kebersihan merupakan suatu kewajiban bagi setiap individu. Selain sebagai anugerah yang diberikan sang pencipta kepada hambanya, kesehatan lingkungan harus tetap dijaga agar terhindar dari berbagai macam penyakit.

Jika dilihat dalam pembelajaran bahasa Indonesia, lingkungan dapat mempengaruhi kualitas belajar dari peserta didik. Menggunakan tema lingkungan dalam pembelajaran bahasa Indonesia dapat memicu minat siswa terhadap pembelajaran bahasa Indonesia dan sangat berimplikasi untuk meningkatkan pengetahuan peserta didik tentang lingkungan. Saat siswa mengalami hal ini, pendidik atau guru dapat mengajak siswa untuk memanfaatkan lingkungan sekitarnya sebagai arahan dan media pembelajaran yang bermanfaat. Dalam pembelajaran ini juga bisa meningkatkan hubungan sosial peserta didik yang mencakup nilai dan norma. Hal ini membantu siswa memikirkan kembali hubungan hidup yang bersih dengan menggunakan lingkungan serta menyadari dan mempertimbangkan persoalan dilingkungan sekitarnya. Guru dapat memberikan materi lingkungan kepada siswa agar siswa dapat memahami pembelajaran dari contoh yang tepat yang bisa ditemui di sekitarnya. Selain guru, siswa juga memiliki peranan yang penting dalam proses pembelajaran. Karena tanpa adanya respon atau tindakan pengaplikasian materi yang diberikan oleh guru, maka tujuan dari pembelajaran teersebut tidak akan dicapai.

Ramadhan et al (2019) pendidikan lingkungan berpengaruh untuk meningkatkan perilaku dan kesadaran atas peserta didik terhadap lingkungan hidup. Pendidikan lingkungan juga dapat membuat peserta didik lebih berpikir secara kritis dan kontekstual. Cara berfikir yang kritis dan kontekstual ini akan berpengaruh nantinya terhadap pembelajaran bahasa Indonesia, oleh kerena itu pendidikan lingkungan dan pembelajaran bahasa saling berkaitan. Menurut Putri dan Syahrul (2019) dalam pembelajaran di lingkungan sekolah, pengajaran membaca harus memperoleh perhatian yang lebih serius dari pendidik di Indonesia. Dengan melalui pengajaran, pendidik mampu mengarahkan peserta didik dalam pembelajaran bahasa. 
Uyar dan Ensar (dalam Ramadhan et al, 2019), mengambil tema lingkungan dalam pembelajaran bahasa Indonesia terutama pada pembelajaran berbasis teks dapat memicu minat peserta didik dalam memahami bahasa, dan secara bertahap dapat meningkatkan pengetahuan peserta didik tentang lingkungan hidup. Pernyataan ini diperkuat lagi oleh Ramadhan et al, (2019) bahwa penting untuk mengembangkan pengetahuan tentang lingkungan, kesadaran lingkungan serta perubahan tingkah laku terhadap lingkungan. Oleh karena itu pembelajaran berbasis lingkungan ini bertujuan untuk membuat peserta didik berpartisipasi dalam melindungi lingkungan yang ada disekitarnya dengan tidak memandang lingkungan sebagai sesuatu yang bisa dieksploitasi untuk kepentingan pribadi saja, melainkan sebagai aset yang berharga dan layak dilindungi untuk kelangsungan hidup manusia.

Menurut Indriyani et al (2019) literasi siswa sangat perlu ditingkatkan terutama pada literasi baca tulis. Kemudian, juga sangat perlu mengetahui bagaimana pelaksanaan literasi yang telah dilaksanakan di sekolah. Penanaman dalam suatu karakter penting ditanamkan sejak siswa masih duduk dibangku sekolah dasar. Penanaman karakter juga dapat dilakukan dalam proses pembelajaran di sekolah. Oleh karena itu banyaknya keragaman pada karakter dan kebiasaan peserta didik di sekolah berasal dari latar belakang keluarga yang berbeda merupakan pengaruh besar sehingga timbulnya hal-hal yang tidak diinginkan dari karakter anak tersebut (Sukma, 2020). Pertanyaan diatas diperjelas lagi oleh Sukma (2017) kemampuan dalam berliterasi sangat berpengaruh terhadap suatu keberhasilan bagi peserta didik dalam menguasai pembelajaran dan kehidupan sehari-hari. Dengan melalui literasi yang baik, akan membantu peserta didik dalam menguasai teks tulisan, teks lisan, dan teks visual. Sukma (2019) mengatakan bahwa guru hendaknya memberikan motivasi kepada siswa. Dengan melalui motivasi tersebut seorang guru akan menciptakan berbagai pengalaman belajar bagi peserta didik.

Berkaitan dengan kreativitas pendapat diatas juga diperjelas oleh Munandar (dalam Pilian et al, 2014) kreativitas adalah hasil dari interaksi individu dengan lingkungannya, maka terlihat dengan jelas bahwa kreativitas individu sangat pada dorongan atau dari motivasi dalam diri dan lingkungannya. Hal-hal yang telah disebutkan sebelum nantinya akan berhubungan dan akan berpengaruh besar terhadap hasil dari proses belajar siswa. Pernyataan tersebut diperkuat oleh pendapat Zulhafizh et al (2013) sikap dan motivasi belajar siswa berkontribusi dan berkaitan dengan hasil belajarnya, yaitu bahasa Indonesia. 
Pendidikan lingkungan mampu membantu peserta didik untuk memikirkan kembali hubungan yang terjadi antara manusia dengan lingkungannya. Hubungan tersebut dimulai dari memahami lingkungannya, dan menyadari akan masalah yang terjadi di lingkungannya, serta mempertimbangkan masalah tersebut dengan kehidupan manusia (Ramadhan et al, 2019). Berkaitan dengan adanya pembelajaran berbasis lingkungan, peserta didik akan lebih optimis terhadap kondisi lingkungan disekitarnya. Oleh karena itu, guru harus memanfaatkan lingkungan untuk melatih, mengajak, membiasakan, dan memotivasi peserta didik berpikir secara kritis dan kreatif. Tidak hanya berpatokan pada siwa saja, melainkan guru juga perlu berpikir kreatif dalam memanfaatkan lingkungan untuk dijadikan media pembelajaran. Dengan demikian guru merupakan fasilitator bagi siswanya. Pendapat ini juga diperkuat oleh Sukma (2012) dan Ramadhan et al (2019) yaitu guru merupakani sebagai fasilitator dan manajer pembelajaran dalam proses belajar dan mengajar.

Ramadhan et al (2018) menyatakan bahwa model pembelajaran yang inovatif akan berpengaruh untuk meningkatkan hasil belajar peserta didik. Oleh sebab itu, pengintegrasian pendidikan lingkungan dalam proses pembelajaran bahasa Indonesia adalah salah satu bentuk cara dalam mewujudkan dan mengembangkan kemampuan dari peserta didik tersebut, sehingga peserta didik dapat berinovasi dan berkolaborasi dengan lingkungan yang ada disekitarnya. Pendapat diatas diperkuat lagi oleh Ramadhan et al (2019) bahwa lembaga pendidikan sebagai pemangku kepentingan utama wajib meningkatkan kesadaran lingkungan peserta didik. Dengan demikian, pendidikan berbasis lingkungan dapat diterapkan dalam mata pelajaran lain, seperti mata pelajaran bahasa Indonesia. Ramadhan et al (2019) mengungkapkan bahwa penggunaan tema lingkungan dalam pembelajaran yang berbasis teks dapat berpengaruh bagi minat siswa belajar bahasa dan secara otomatis akan mampu meningkatkan pengetahuan siswa tentang lingkungan.

Berdasarkan angket yang penulis sebarkan mengenai "Pengaruh Lingkungan dalam Pembelajaran Bahasa Indonesia" kepada mahasiswa universitas Negeri Padang semester 5. Dari hasil keseluruhan yang ikut berpartisipasi mengisi angket tersebut yaitu berjumlah 32 responden, rata-rata yang mengisi angket tersebut perempuan dengan jumlah 29 responden, dan laki-laki 3 responden. Hasil dari pengisian angket yang telah dilakukan melalui google form tersebut dapat dilihat sebagai berikut : 
Pernyataan pertama "Pembelajaran berbasis lingkungan merupakan pembelajaranyang menekankan lingkungan sebagai media atau sumber belajar" ini mengacu pada responden setuju (S) 53,1\%, sangat setuju (SS) 43,8\%, kurang setuju (KS) 0\%, dan tidak setuju (TS) $0 \%$. Pertanyaan kedua "Membuat suatu karya sastra dengan menggunakan Lingkungan", juga dapat dilihat pada hasil responden yang banyak mengatakan setuju (S) 62,5\%, dari pada sangat setuju (SS) 31,3\%, dan kurang setuju (KS) 10,1\%, dan Tidak setuju (TS) 9,8\%. Pernyataan ketiga "Menghidupkan karya sastra dengan tema lingkungan", pernyataan seperti ini juga mengundang perhatian dari responden yaitu dengan mengatakan setuju (S) 62,5\% lebih banyak dibandingkan dengan Sangat setuju (SS) 31,3\%, dan kurang setuju (KS) 6,3\%. Pernyataan ke empat "Mengambil objek yang unik dalam lingkungan pada pembuatan dongeng", juga mengarah pada hasil setuju (S) 50\%, sedangkan hasil sangat setuju (SS) 46,9\%, dan hasil kurang setuju (KS) 3,1\%. Pernyataan kelima "Dalam pembelajaran bahasa Indonesia materi tentang lingkungan harus diterapkan sejak dini", pernyataan seperti ini memperoleh hasil lebih maksimal pada setuju (S) 65,6\%, dibandingkan dengan hasil sangat setuju (SS) 34,4\%, hasil kurang setuju (KS) 0\%, dan tidak setuju (TS) $0 \%$. Pernyataan ke enam "Pembelajaran berbasis lingkungan bertugas untuk membuat siswa berpatisipasi dalam melindungi lingkungan", dapat dilihat pada hasil responden sangat setuju (SS) 34,4\%, setuju (S) 62,3\%, kurang setuju (KS) 3,1\%, dan tidak setuju (TS) $0 \%$. Pernyataan ketujuh " Teks cerpen yang mengkaitkan lingkungan dalam pembelajaran bahasa Indonesia", pernyataan seperti itu sangat berpengaruh pada hasil setuju (S) dari responden $68,8 \%$, sedangkan pada hasil sangat setuju (SS) $28,1 \%$, pada hasil kurang setuju (KS) hanya berpatokan 3,1\%, dan hasil tidak setuju (TS) $0 \%$. Pernyataan kedelapan "Lingkungan yang bersih adalah salah satu penunjang agar terlaksana Pembelajaran yang baik", Pernyataan seperti ini memperoleh hasil data dari responden yaitu sangat setuju (SS) 37,5\%, setuju (S) 56,4\%, kurang setuju (KS) 6,3\%, dan tidak setuju (TS) 0\%. Pertanyaan kesembilan "Upaya pelestarian lingkungan dapat dilakukan dengan melalui teks bacaan dalam pembelajaran bahasa Indonesia", pernyataan seperti ini juga memperoleh hasil data dari responden yaitu sangat setuju (SS) 25\%, setuju (SS) 75\%, kurang setuju 0\%, dan tidak setuju juga 0\%. Terakhir pernyataan kesepuluh "Teks narasi dengan tema lingkungan dalam pembelajaran bahasa Indonesia", pernyataan ini memperoleh hasil data dari responden yaitu sangat setuju ( SS) 31,3\%, setuju (S) 59,3\%, kurang setuju (KS) 9,4\%, dan tidak setuju (TS) $0 \%$. 
Dari hasil penyebaran angket yang telah dilakukan, dapat penulis simpulkan bahwa lingkungan sangat berpengaruh penting dalam pembelajaran bahasa Indonesia, terutama untuk menumbuhkan kesadaran siswa terhadap perlunya menjaga kebersihan. Pendidikan lingkungan dapat dimasukkan langsung kedalam proses pembelajaran bahasa Indonesia. Dapat dilihat dari buktinya responden lebih cenderung menganggap lingkungan berkaitan erat dengan pembelajaran bahasa Indonesia. Penulis berharap dengan adanya menerapan pendidikan lingkungan yang ada pada pembelajaran bahasa Indonesia dapat menjadikan lingkungan menjadi lebih baik untuk kedepannya. Sama-sama kita ketahui bahwa lingkungan sangat berpengaruh terhadap pembelajaran dan memiliki peran penting bagi kehidupan. 


\section{Daftar Pustaka}

Putri, Diana dan Syahrul R. (2019). Korelasi Keterampilan Membaca Pemahaman dan Keterampilan Menulis Teks Laporan Hasil Observasi Siswa Kelas VII SMP Negeri 4 Pariaman. Jurnal Pendidikan Bahasa dan Sastra Indonesia, 8(1), seri A 62-69.

Piliang, Wilda S. H., Atmazaki, dan Syahrul Ramadhan. (2014). Kontribusi Kemampuan Apresiasi Sastra dan Berpikir Kreatif terhadap Keterampilan Bermain Drama pada Siswa Kelas XII IPS SMA Negeri 2 Rengat Kabupaten Indragiri Hulu. Jurnal Bahasa, Sastra dan Pembelajaran, 2(2), 75-87.

Ramadhan, S., Yasnur Asri, dan Vivi Indriyani. (2018). Learning Module Design Writing Argumentative Text Based Problem-Based Learning. Advances in Social Science, Education and Humanities Research, Vol 263: 194-200.

Ramadhan, S., Elfia Sukma, dan Vivi Indriyani. (2019). Environmental Education and Disaster Mitigation Through Language Learning. IOP Conference Series: Earth and Environmental Science, 314, p. 1-9.

Ramadhan, S., Elfia Sukma, dan Vivi Indriyani. (2019). Persepsi Guru terhadap Penggunaan Bahan Ajar Bahasa Indonesia dengan Perangkat Seluler dan Aplikasi Edmodo. Seminar Internasional Riksa Bahasa.

Sukma, Elfia. (2012). Pembelajaran Sastra yang Integratif Berbasis Kompetensi. International Conference on Languages and Arts, Halaman 432-436.

Sukma E, Ritawati M, dan Rizky A. (2017). Literacy Media Development in Improving Reading and Writing Skill of Early Class Students in Elementary School Padang Utara Padang. Advances in Social Science, Education and Humanities Research, Vol 118.

Sukma E. et.al. (2019). Problems in Oral Language Teaching in Primary School. Advances in Social Science. Education and Humanities Research, Volume 301.

Sukma E, dan VP Azrianti. (2020). Instilling Positive Characters in Students Using Folker in the Macromedia Application. Advances in Social Science, Education and Humanities Research, Volume 485. 
Zulhafizh, Atmazaki, dan Syahrul Ramadhan. (2013). Kontribusi Sikap dan Motivasi Belajar Siswa terhadap Hasil Belajar Bahasa Indonesia. Jurnal Bahasa, Sastra dan Pembelajaran, Volume 1, Nomor 2, Halaman 13-28. 